\title{
EVALUATION OF ANTHROPOGENIC ACTIVITIES IN UDYAVARA RIVER BASIN, SOUTH WEST COAST OF INDIA
}

\author{
B S Maddodi ${ }^{1}$, Prajas ${ }^{2}$, H N Udaya Shankara ${ }^{3}$ \\ ${ }^{1}$ Department of Civil Engineering, Manipal Institute of Technology, Manipal, Karnataka, India \\ ${ }^{2}$ M. Tech (130950021), Environmental Engineering, Manipal Institute of Technology, Manipal, Karnataka, India \\ ${ }^{3}$ Department of Civil Engineering, Manipal Institute of Technology, Manipal, Karnataka, India
}

\begin{abstract}
River environment is one of the highly water yielding place for present generation. It is influenced by geomorphic processes like shoreline erosion, siltation, sedimentation, flooding etc. Modification in river ecology is also influenced by the estuaries and sea. Most of the population will be alongside the river basin fetching river water for daily use. In this project work, Udyavara river basin is taken into consideration which is also prevailing at the coastal belt of Karnataka in Udupi district. Udyavara River incorporates the catchment that feed into the estuaries, coastlines and the groundwater that underlies the river basin. Increasing population, industrialization, solid waste dumping and improper sanitary conditions may contaminate the river water for future use. This study considers implementing of measures aimed at maintaining and improving the aquatic environment by restriction to adverse anthropogenic activities. Recently environmental problems have arisen in the river basin which is leading to monitoring and settling environmental objectives for groundwater and surface water pollution. The overall objective of the present study is to prevent deterioration and achieve environmental improvement. It can be concluded based on the results that environmental problems can be solved in this stage and sustainability can be achieved.
\end{abstract}

Keywords: Udyavara River Basin, anthropogenic activities, third order, riverine environment, water pollution, water quality

$* * *$

\section{INTRODUCTION}

Udyavara River is one of the rivers situated in south west part of India influenced by the coastal zone of Arabian Sea. The path of a river basin is continuously influenced by geomorphic processes like erosion, deposition, sedimentation, periodic storms and floods and changing sea level. Increasing population, industrial establishments and developments are common in and near river banks. Soil erosion is the biggest problem in river coasts and poses greater threats by destruction of natural habitats and destruct agro-ecosystem and a growing burden of pollution. Life in Karnataka's rivers, lakes, estuaries and the seas is under greater stress than that on the land. The area of study experiences a typical maritime climate with an average temperature of $26.5^{\circ} \mathrm{C}$ [14]. Coastal Karnataka is emerging as an urbanized region giving rise to industrial growth. The rapid industrialization must be restricted to reduce pollution of water of rivers which joins sea. Though many big industries have withdrawn due to peoples' movement, the region is still the destination for investment. Fishing is the main occupation of people residing near coastal plains thus fish mills are established increasing the employment among people. Pollution of water is not only caused by the nutrients and salts but also by solid waste generated due to anthropogenic activities. River acts as a sink to many types of pollutants due to unscientific sanitation in adjacent areas, port activities and effluent discharge by industries of different kind and dumping of fish and organic wastes. Eutrophication problems may also arise due to nutrients degrading water quality and posing threat to aquatic organisms. If industrial effluents have toxic chemicals, bioaccumulation of pollutants in aquatic organisms can be noticed. The population is expected to increase due to industrialization, urbanization, and widening of roads in Udupi district where Udyavara is a part. Water pollution problems will also increase alongside developmental activities. Groundwater exploitation is increasing day by day everywhere. Manual survey of different places in Udupi district give an outline of problems posed due to anthropogenic activities in brief. Quantitative estimates and monitoring helps to overcome the environmental issues and problems related to river ecology, sustainability and river developments.

\section{STUDY AREA}

\subsection{Introduction to the Udyavara River Basin}

Focusing on the much needed attentiveness to Udupi for the solution towards the water quality, geological, environmental, socio-economic changes provoking problems, the present study is done. The area of study is Udyavara river basin which is located in Udupi district which lies in southwest coast of Karnataka. It lies between the latitude of $13^{0} 00^{\prime} 00^{\prime \prime}-13^{0} 45^{\prime} 00^{\prime \prime}$ north and longitude of $74^{\circ} 47^{\prime} 30^{\prime}-74^{0} 30^{\prime} 00^{\prime}$ ' east respectively. It spans an area of 422 sq. kms. The area under investigation is accounted for in the survey of India maps No. 48K/ 11, 12, 15, 16; 48/ 4 [4]. 
The river ecosystem which is $21 \mathrm{kms}$ in length has contributed for ecology and sustainable development and rising environmental and socio-economic issues. Anthropogenic activities and fast urbanization may degrade the river water quality. Continuous monitoring and a necessity of in-depth and holistic baseline data acquisition and interpretation in inland use/land-cover, hydrological study, observing the changes in the chemical and biological composition of the basin through time bound is needed.

The main objective of the study is to understand and estimate the impact of water pollution by the anthropogenic activities on the third order river points. The south west monsoon brings a lot of rains both to the coast and the ghat sections. During monsoon period, i.e. June to September, as there is heavy down pour, the rivers and streams of Western Ghats flow westward though the lengths of the rivers are short but carry a huge volume of water.
Rivers are perennial during normal rainfall years where as tributaries and smaller streams become dry during summer [14]. Slope of the terrain varies widely from $2^{0}$ to $14^{0}$. The north central parts of the basin are low energy depositional environments. Rest of the basin is of relatively higher energy [4]. The prevailing high gradient in the hilly terrain and heavy rainfall brings great volume of water in these rivers during monsoon. These rivers join Arabian Sea and are prone to tidal effects to considerable lengths in the inland area.

\subsection{Hydrology Map of Udyavara River Basin}

Fig-1 below shows the hydrology of basin. The riverine ecosystem covers the maximum area of the total area where most of the third order river points flows and narrows towards the western part of the basin.

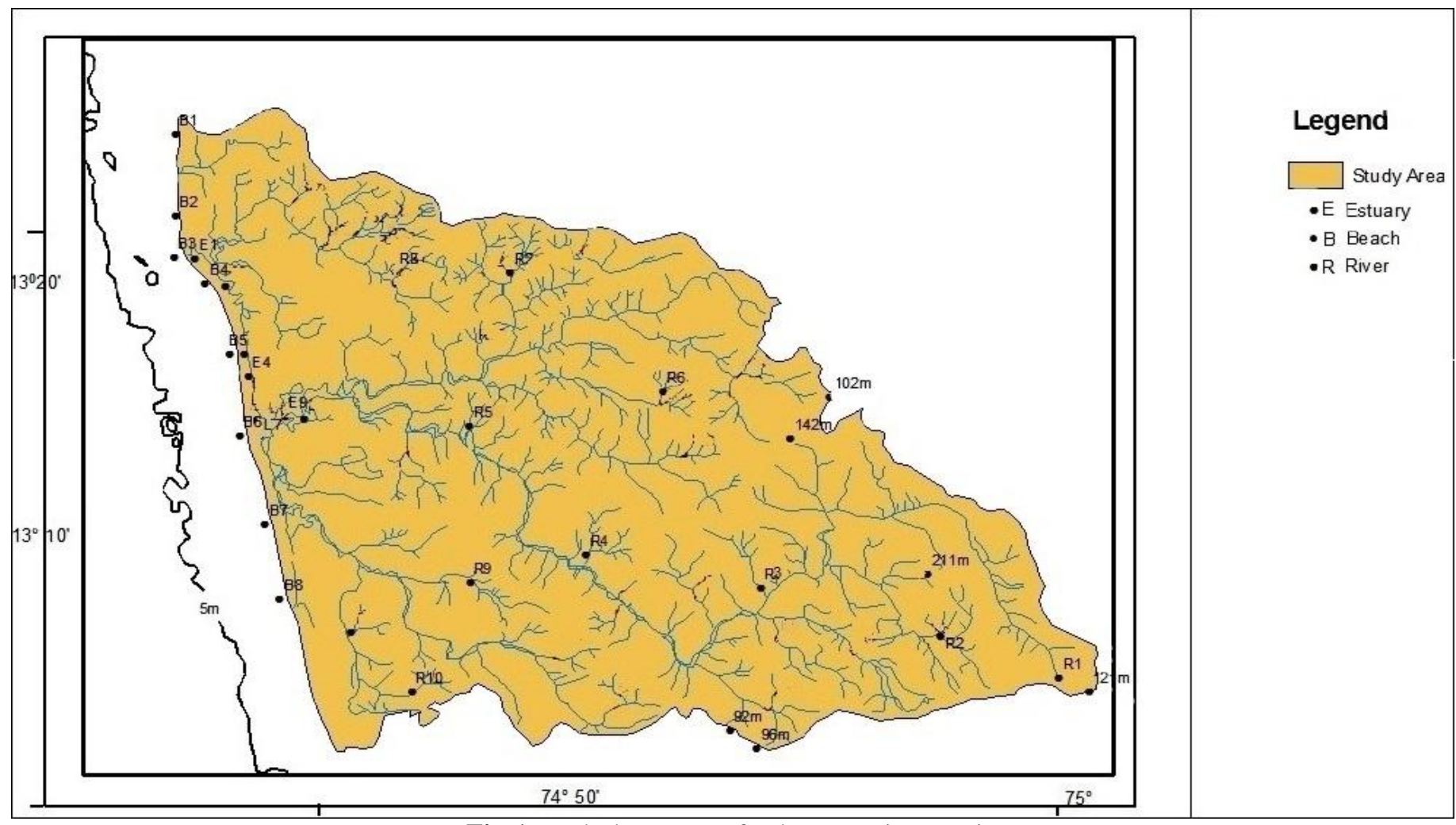

Fig-1: Hydrology map of Udyavara River Basin

\section{METHODOLOGY}

This part mainly deals with the details about the step by step procedure followed in each work done, how it is done and using what equipments, method of analysis adopted in order to get the results from the analysis part. All the experiments were conducted according to Standard methods for the examination of water and wastewater, APHA $21^{\text {st }}$ Edition, 2005.

Sampling is done in 9 third order river points of Papanashini and Udyavara rivers from R2-R10 and 1 lake point R1 i.e., Anekere. The sampling station to be sampled throughout the basin was also marked in the maps after selecting them. Surface water samples were collected with clean bottles. After the analysis of waters from different places, Turbidity was measured using Elico CL 52D Nephelometer. pH, Conductivity, Total Dissolved Solids, Salinity and Resistivity were measured using Hach multi-meter.

Summer season, in the month of March was considered for sampling of third order river points for identifying greater impacts. In the field, co-ordinates of sampling points were also noted. Samples were kept in Rotek Deep freezer until analysis for all the parameters was undertaken. Initial dissolved oxygen and Biochemical oxygen demand was 
measured using Winkler's method by $0.01 \mathrm{~N}$ Sodium Thiosulphate as Titrant and Biochemical oxygen demand at $20^{\circ} \mathrm{C}$ for 5 days in Rotek incubator with $5 \%$ dilution for initial and final oxygen demand. Most Probable Number of bacteria was counted using 3 sets of 5 tubes by sterilizing in a Rotek autoclave. Chemical oxygen demand was analyzed using $0.25 \mathrm{~N}$ Ferrous Ammonium Sulphate and $\mathrm{KMnO}_{4}$. Finally Nitrates were analyzed by Devarda's Alloy Method. Heating in both Chemical oxygen demand and Nitrates experiments used Mac Kjeldal digestion unit. Variation in the measured parameters were noted which are highlighted for conclusion from the results obtained after analysis. The river name, co-ordinates and names of places were also marked which is shown in Table-1.

Table-1: Names and co-ordinates of the sampling points

\begin{tabular}{|l|l|l|}
\hline Point & Place name & Co-ordinates \\
\hline R1 & Anekere lake & $13^{0} 12^{\prime} 20.67^{\prime \prime} \mathrm{N}$ \\
$74^{0} 59^{\prime} 52.49^{\prime \prime} \mathrm{E}$ \\
\hline R2 & Bajakala & $13^{0} 12^{\prime} 54.6^{\prime \prime} \mathrm{N}$ \\
& & $74^{0} 56^{\prime} 32.91^{\prime \prime} \mathrm{E}$ \\
\hline R3 & Kallya- Papanashini river & $13^{0} 13^{\prime} 24.01^{\prime \prime} \mathrm{N}$ \\
$74^{0} 53^{\prime} 25.84^{\prime \prime} \mathrm{E}$
\end{tabular}

\begin{tabular}{|c|c|c|}
\hline $\mathrm{R} 4$ & Kodu- Papanashini river & $\begin{array}{l}13^{0} 24^{\prime} 34.48^{\prime \prime} \mathrm{N} \\
74^{0} 49^{\prime} 25.98^{\prime \prime} \mathrm{E}\end{array}$ \\
\hline R5 & Belle- Papanashini river & $\begin{array}{l}13^{0} 16^{\prime} 32.65^{\prime \prime} \mathrm{N} \\
74^{0} 48^{\prime} 3.73^{\prime \prime} \mathrm{E}\end{array}$ \\
\hline R6 & Kodangala & $\begin{array}{l}13^{0} 18^{\prime} 8.87^{\prime \prime} \mathrm{N} \\
74^{0} 48^{\prime} 10.8^{\prime \prime} \mathrm{E}\end{array}$ \\
\hline R7 & Pernankila & $\begin{array}{l}13^{0} 17^{\prime} 41.85^{\prime \prime} \mathrm{N} \\
74^{0} 50,54.24^{\prime \prime} \mathrm{E}\end{array}$ \\
\hline $\mathrm{R} 8$ & Alewoor & $\begin{array}{l}13^{0} 17^{\prime} 59.88^{\prime \prime} \mathrm{N} \\
74^{0} 46^{\prime} 45.45^{\prime \prime} \mathrm{E}\end{array}$ \\
\hline R9 & Panjimar & $\begin{array}{l}13^{0} 13^{\prime} 57.63^{\prime \prime} \mathrm{N} \\
74^{0} 47^{\prime} 48.69^{\prime \prime} \mathrm{E}\end{array}$ \\
\hline $\mathrm{R} 10$ & Shanthigudde & $\begin{array}{l}13^{0} 12^{\prime} 4.93 ” \mathrm{~N} \\
74^{0} 47^{\prime} 49.22^{\prime \prime} \mathrm{E}\end{array}$ \\
\hline
\end{tabular}

\section{RESULTS}

Results are based on parameters of third order river waters and a lake obtained by analysis in different sampling points of Udyavara River Basin. These results help in knowing the level of pollution in third order river points for water resource management in the region. Table- 2 gives the third order river water quality parameters.

Table-2: Third order river water quality parameters

\begin{tabular}{|l|l|l|l|l|l|l|l|l|}
\hline Point & R1 & R2 & R3 & R4 & R5 & R6 & R7 & R8 \\
\hline Parameter & 4.14 & 6.15 & 6.59 & 6.88 & 7.19 & 6.77 & 7.04 & 6.86 \\
\hline EH & 245 & 49.7 & 58.1 & 82.5 & 85.9 & 295 & 65.9 & 137 \\
\hline Total Dissolved Solids $(\mathrm{mg} / \mathrm{L})$ & 117.1 & 23.3 & 27.3 & 38.8 & 40.5 & 141 & 31 & 64.8 \\
\hline Salinity $(\%$ ) $)$ & 0.12 & 0.02 & 0.03 & 0.04 & 0.04 & 0.14 & 0.03 & 0.06 \\
\hline Resistivity $(\mathrm{k} \Omega . c m)$ & 4.08 & 20.13 & 17.21 & 12.13 & 11.63 & 3.39 & 15.18 & 7.30 \\
\hline Turbidity $(\mathrm{NTU})$ & 3.7 & 13.5 & 5.5 & 6.4 & 5.8 & 9 & 11 & 11 \\
\hline Initial Dissolved Oxygen $(\mathrm{mg} / \mathrm{L})$ & 4.0 & 3.84 & 5.5 & 3.96 & 4.64 & 4.48 & 4.48 & 4.80 \\
\hline Biochemical Oxygen Demand $(\mathrm{mg} / \mathrm{L})$ & 54.4 & 22.4 & 58.8 & 21.6 & 6.4 & 41.6 & 35.2 & 16 \\
\hline Chemical Oxygen Demand $(\mathrm{mg} / \mathrm{L})$ & 72 & 28 & 80 & 64 & 64 & 104 & 96 & 96 \\
\hline Most Probable Number/ $100 \mathrm{ml}$ & $\geq 2400$ & $\geq 2400$ & $\geq 2400$ & $\geq 2400$ & 920 & $\geq 2400$ & $\geq 2400$ & $\geq 2400$ \\
\hline Nitrates $(\mathrm{mg} / \mathrm{L})$ & 7 & 5 & 4 & 2 & 5 & 8 & 8 & 7 \\
\hline
\end{tabular}

Water is more acidic at lake $\mathrm{R} 1$ having $\mathrm{pH} 4.14$ and near neutral in other points of the consistent range 6.15-7.19 shown in Chart-1. Electrical conductivity is in the range of 49.7-295 in $\mu \mathrm{S} / \mathrm{cm}$ having peak value at river point R6. Lake $\mathrm{R} 1$ also has a high value at $245 \mu \mathrm{S} / \mathrm{cm}$ as shown in the Chart2. The values of Total Dissolved Solids have exactly the same pattern as that of Electrical conductivity in lake and river points provided they are in the range $23.3-141 \mathrm{in} \mathrm{mg} / \mathrm{L}$ shown in Chart-3.

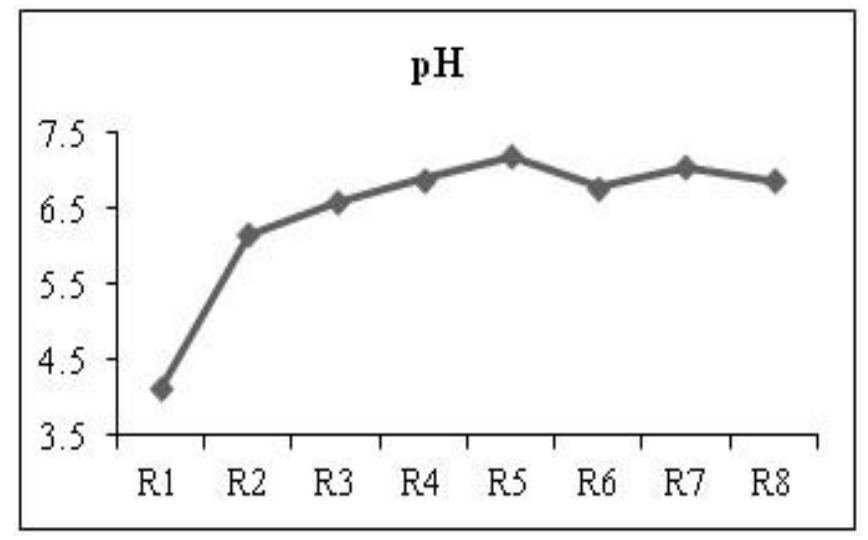

Chart-1: Variation of $\mathrm{pH}$ in third order river water samples 


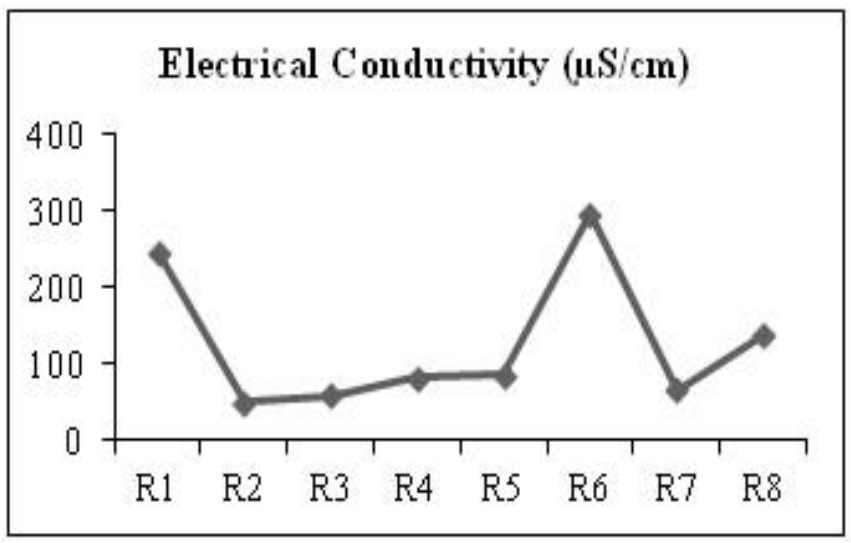

Chart-2: Variation of Electrical Conductivity in third order river water samples

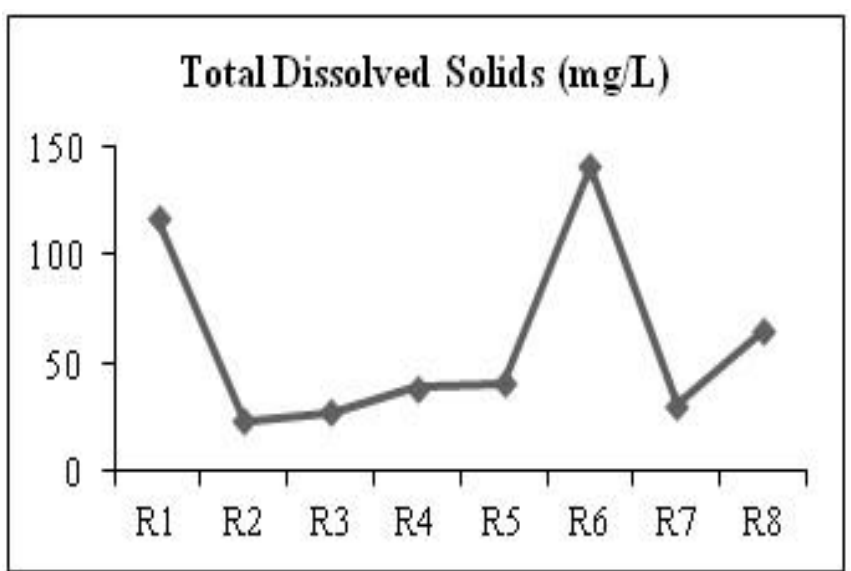

Chart-3: Variation of Total Dissolved Solids in third order river water samples

Very less Salinity $(\% 0)$ in the range of 0.02-0.16 are analyzed where 2 peak points at rivers R6 and R8 and Lake R1 are seen as in the Chart-4. Resistivity in $\mathrm{k} \Omega$.cm follows opposite trend of Salinity and in the range 3.39-20.13. A very high Resistivity at point R2 is present as in Chart-5. Turbidity is very less in the lake at 3.7NTU and in rivers; a wide range of 5.5-13.5 NTU is present. Peak value is at R2 and the graph varies as in Chart-6.

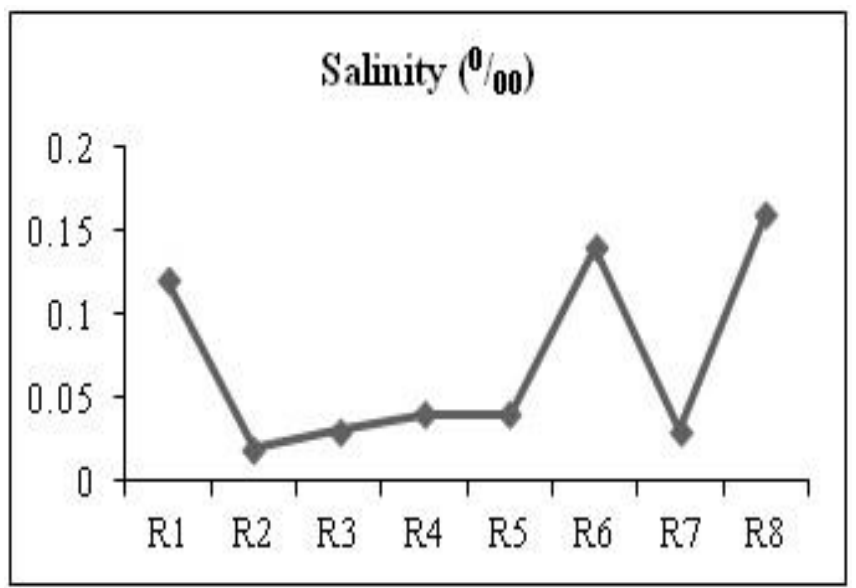

Chart-4: Variation of Salinity in third order river water samples

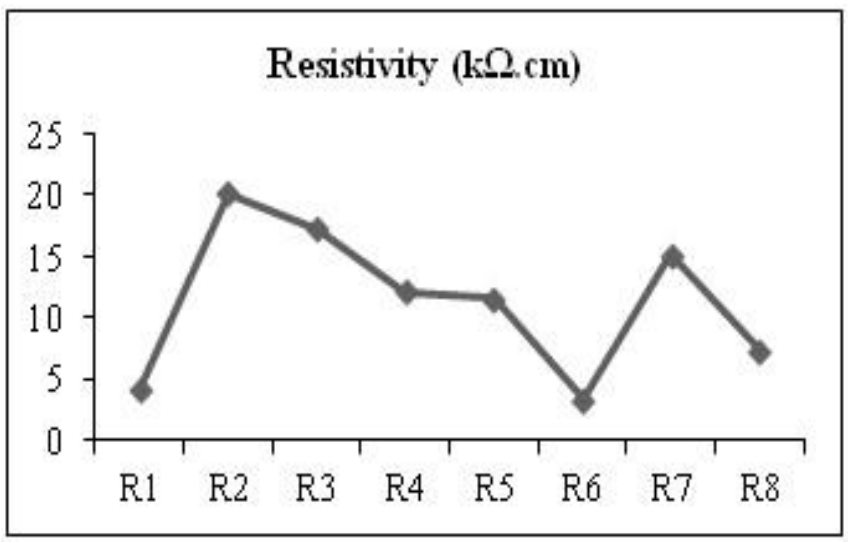

Chart-5: Variation of Resistivity in third order river water samples

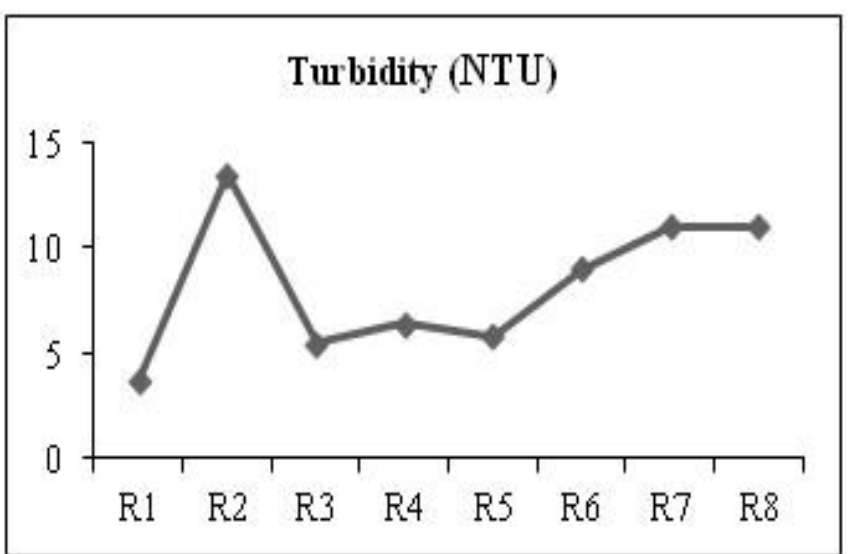

Chart-6: Variation of Turbidity in third order river water samples

Initial Dissolved Oxygen at all points is less and only point $\mathrm{R} 3$ has higher content out of the range 3.84-5.5 in $\mathrm{mg} / \mathrm{L}$ as represented in Chart-7. A wide range of Biochemical Oxygen Demand values are analyzed in the range of 6.4-58.8 in $\mathrm{mg} / \mathrm{L}$ where high values are at point R1 of the lake and point R3 of the river and lowest value at point R5, shown in Chart-8. Chemical Oxygen Demand is present in the range of 28-104 in $\mathrm{mg} / \mathrm{L}$ which is in the Chart-9.

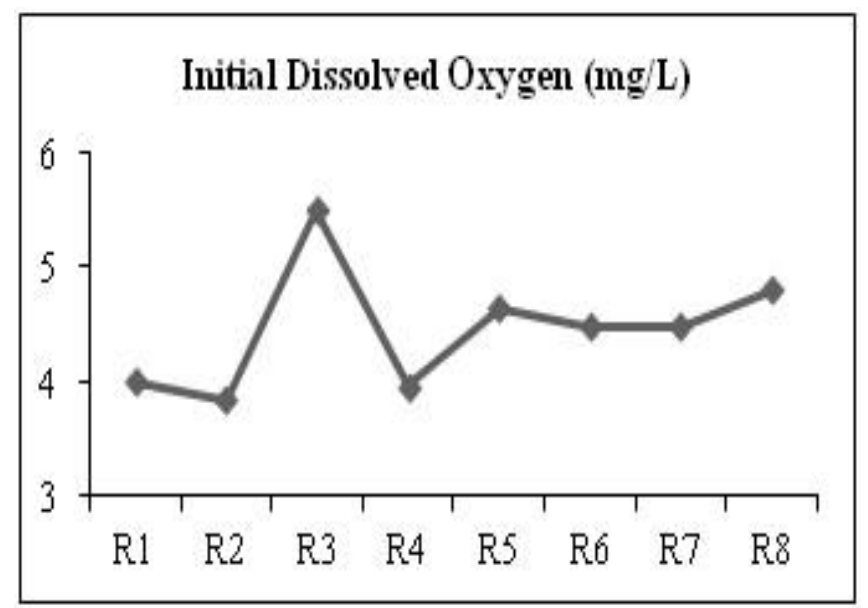

Chart-7: Variation of Initial Dissolved Oxygen in third order river water samples 


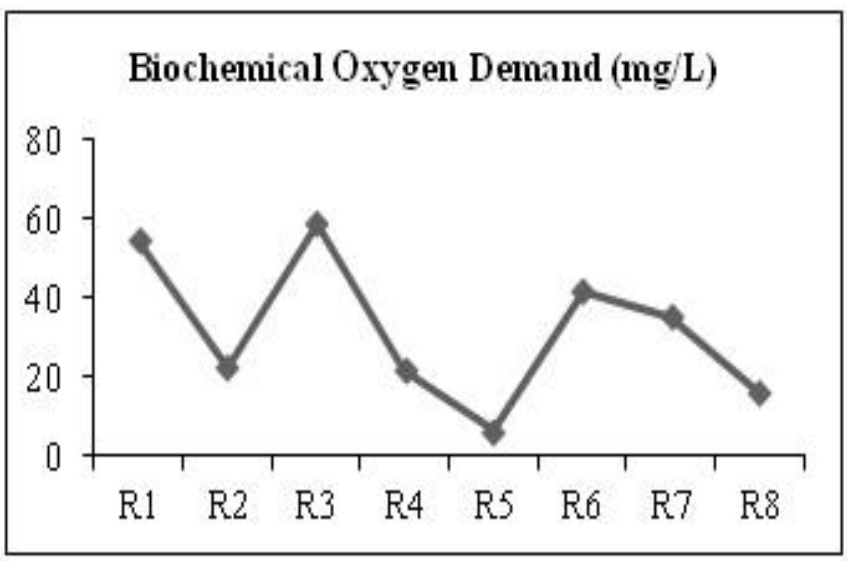

Chart-8: Variation of Biochemical Oxygen Demand in third order river water samples

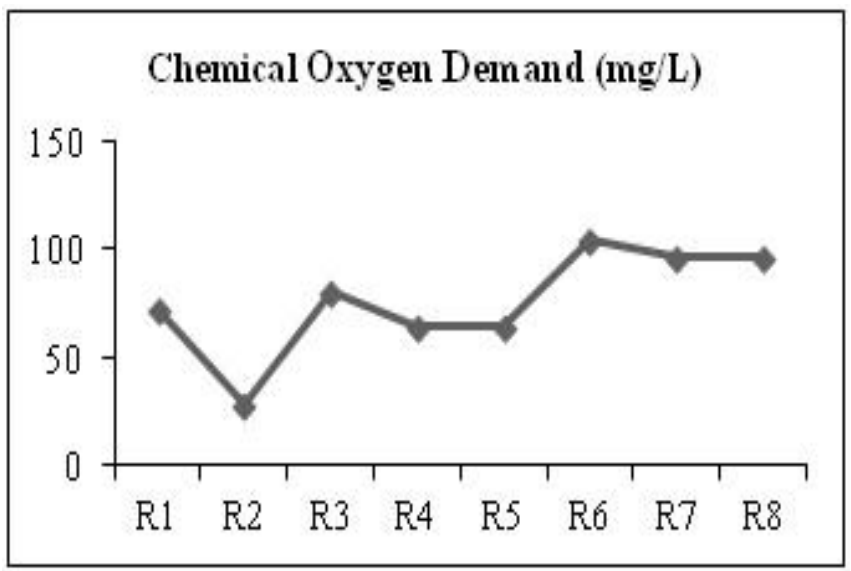

Chart-9: Variation of Chemical Oxygen Demand in third order river water samples

Bacterial count is found very high per $100 \mathrm{ml}$ in all points except R5 as analyzed by Most Probable Number technique as in the Chart-10. Very less Nitrate content is present at point $\mathrm{R} 4$ out of the range $2-8 \mathrm{in} \mathrm{mg} / \mathrm{L}$ represented in the Chart-11.

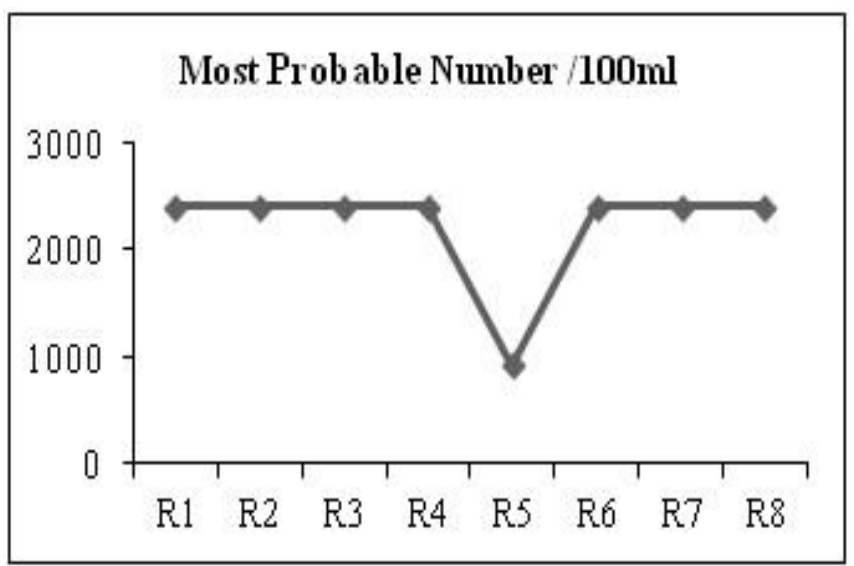

Chart-10: Variation of Most Probable Number in third order river water samples

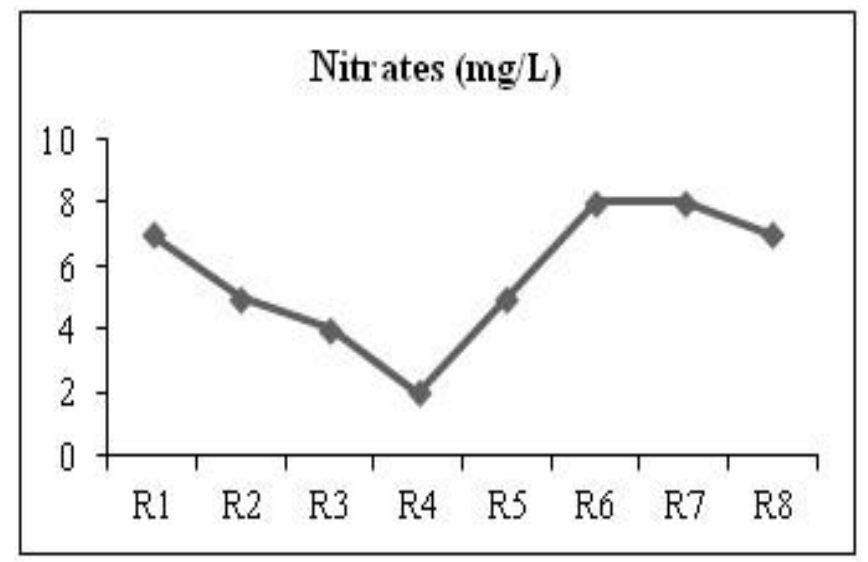

Chart-11: Variation of Nitrates in third order river water samples

\section{CONCLUSION}

Scarcity of water will arise during late winter and early summer. The wells will be dry and rivers will be in no flow conditions in many places. No water conservation programmes or artificial recharge schemes have been implemented in Udupi district [14]. Immediate need for water resource management in the river points by adopting water conservation practices. Anthropogenic activities in the basin have polluted water in almost all the streams. Some of them are disposal of organic and inorganic wastes into rivers, leaching of pesticides and chemical fertilizers from farmlands and improper sanitary conditions. Bacterial count in higher concentration in human habitat region means there is a need for prevention of disposal of organic wastes into water bodies from industries and domestics. Amount of rainfall in the area is reducing in the recent years [14] due to deforestation and thus afforestation in process will reduce soil erosion and also provide home for some rare species of birds. Sanitary conditions are not maintained and monitored along with solid waste management throughout the region of study which must be done alongside developmental activities. Lake R1 must be preserved from eutrophication and death of lake. River points R9 and R10 were dry and no flow condition prevailed there. Nearby wells was also dry indicating the scarcity of water in the beginning of summer only.

\section{ACKNOWLEDGEMENTS}

We are thankful to Manipal Institute of Technology and all the faculty members of civil Engineering Department for their support and guidance for the completion of the project. We express great sense of gratitude to all our friends for their valuable and moral support throughout the process of completion of this work.

\section{REFERENCES}

[1] A. A. Ghani, R. Ali, N. A. Zakaria, Z. A. Hasan, C. K. Chang, and M. S. S. Ahamad, "A temporal change study of the Muda river system over 22 years," Int. J. River Basin Manag., vol. 8, no. 1, pp. 25-37, 2010. 
[2] American Public Health Association, Standard methods for the examination of water and wastewater, 21st Edition, 2005.

[3] B. K. H. Kumara, S. Srikantaswamy, and S. Bai, "Environmental flows in Bhadra river, Karnataka, Intl. J. Water Resour. Environ. Eng., India," vol. 2, no. November, pp. 164-173, 2010.

[4] B. S. Maddodi, “Evaluation of the fluvial and coastal geomorphometric and sedimentologic systems: A study of the Udyavara basin, west coast, India," , MPhil., Thesis, Department of Marine Geology, Mangalore University, 1996.

[5] B. Suresh, "Multiplicity of phytoplankton diversity in Tungabhadra river near Harihar, Karnataka (India)," Int. J. Cur. Micro. App. Sci, vol. 4, no. 2, pp. 10771085, 2015.

[6] C. S. Rao, "National Seminar on Water \& Culture, Hampi, Bellary Dist: 25-27, June 2007 Title: participatory irrigation management (PIM) in Andhra Pradesh - an overview," National seminar on water \& culture, Culture, no. June, pp. 25-27, 2007.

[7] D. A. Swamy, B. E. Basavarajappa, and P. E. T. Puttaiah, "Coastal zone environmental management in Udupi district," Int. J. Eng. Sci, vol. 1, no. 3, pp. 8$11,2012$.

[8] Francis Andrade, H. B. Aravinda and E. T. Puttaiah, "Studies on Mangalore coastal water pollution and its sources," Indian J. Sci. Tech, vol. 4, no. 5, pp. 553557, 2011.

[9] G. V Lugomela, H. Beuster, and P. M. Patrick, "IUCN Water and nature initiative Pangani basin water board 1 Pangani river basin flow assessment hydrology and system analysis volume 2 of 2 : development and application of a system model for the Pangani river basin," vol. 2, no. October 2009, 2010.

[10] L. C. S. Reddy, S. M. Deshpande, K. V. R. Reddy, and K. R. Aher, "Hydro geochemical processes in the groundwater environment of Vemula area , Kadapa District , South India," Int. J. Recent Trends Sci. Technol., vol. 3, no. 1, pp. 18-24, 2012.

[11] Maddodi, B S and Udayashankar, H N and Shenoy, Narayan K N and Raghavan, B R (2015), "Geochemical Evaluation of an estuarine environment: A case study on Udayavara Estuary South West Coast of Udupi, India," Int. J. Adv. Struct. Geotech. Eng., 04 (01), pp. 36-39. ISSN 2319-5347.

[12] Maddodi B S and Udayashankar, H N and Raghavan, B R (2011), "Computing of Udyavara Fluvial Systems - A River of Western Ghats, India: A Pragmatic Inference of Runoff to Hydrological Cycle," Int. J. Earth Sci. Eng., 4 (7). pp. 349-350. ISSN 0974-5904.

[13] Maddodi, B S, Udayashankar, H N, Raghavan, B R and Mathews, Alina E (2013), "An assessment of the spatial relativity of health, Literacy and socioeconomic growth index using gis Techniques: a case study on udupi south west coast of India, karnataka," In: 1st Annual Int. Interdiscipl. Conference, 24-26 April 2014, Azores, Portugal.
[14] Ministry of water resources, Govt. of India, "Ground water information booklet, Udupi district, Karnataka state," no. December, pp. 1-23, 2008.

[15] M. A. Nkansah, N. O. Boadi, and M. Badu, "Assessment of the quality of water from hand-dug wells in Ghana.," Environ. Health Insights, vol. 4, pp. 7-12, 2010.

[16] M. S. Shruthi, V. R. Sushanth and M. Rajashekhar, "Diatoms as indicators of water quality deterioration in the estuaries of Dakshina Kannada and Udupi Districts of Karnataka," Int. J. Environ. Sci., vol. 2, no. 2, pp. 996-1006, 2011.

[17] Patil S. S. and Ghorade I. B. "Assessment of physicochemical characteristics of Godavari river water at Trimbakeshwar \& Kopargaon, Maharashtra (India)," Indian J. App. Res., no. March, pp. 149-152, 2013.

[18] P. I. Bhat, S. S. Cristopher, and B. B. Hosetti, "Avifaunal diversity of Anekere wetland, Karkala, Udupi district, Karnataka, India," J. Environ. Bio., vol. 30, no. November, pp. 1059-1062, 2009.

[19] Shivasharanappa and A. Yalkpalli, "Hydrogeochemical analysis of Bhima river in Gulbarga district," vol. 2, no. 4, pp. 862-882, 2012.

[20] Shivasharanappa and A. Yalakpalli, "Study on the physico-chemical and biological characteristics of Bhima river in Gulbarga district, Karnataka state, India," Int. J. Pharm. Res., vol. 3, no. 1, pp. 96-108, 2012.

[21] S. Basu and K. S. Lokesh, "Evaluation of cauvery river water quality at Srirangapatna in Karnataka using principal component analysis," vol. 1, no. 4, pp. 6-12, 2012.

[22] S. M. Avvannavar, "Studies on pollution of river Nethravathi, Karnataka," Nature Environ. Poll. Tech., vol. 6 , no. 3, 2007.

\section{BIOGRAPHIES}

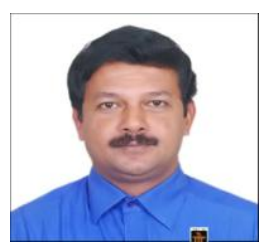

Mr. B S Maddodi is an Assistant Professor (senior scale) in the Department of Civil Engg., Manipal Institute of Technology, Manipal University, Manipal, Karnataka India having $17 \mathrm{yrs}$. of experience in teaching and research. Participated in National and International Workshops, Conferences, Seminar and Symposium with more than 15 publications in Reputed Journal and Conference Proceedings.

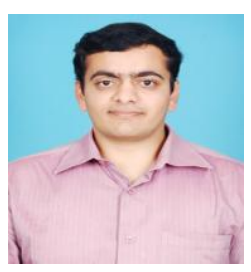

Mr. Prajas is a student of M.Tech in Environmental Engineering in Manipal Institute of Technology, Manipal, Karnataka, India. After completing B.E. in Environmental Engineering for esteemed VVCE Mysore with distinction, he joined M.Tech in Environmental Engineering at MIT Manipal, Manipal University and secured 7.56 CGPA and with depth research knowledge during his M.Tech Program 


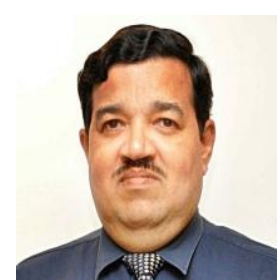

Dr. H N Udaya Shankara is Professor in the Department of Civil Engineering with specialization in Landform Analysis using Remote Sensing. He is the Fellow of Geological Society of India and Fellow Mineralogical Society of India. He is having a professional engagement with Association of Exploration of Geophysicists as a Life Member. He is having more than 30 publications in Reputed National and International Journals and Conference Publications. His expertise deals with Remote Sensing, Geomorphology, Hydrogeology, and Environmental Studies 